\title{
Short story classics
}

\author{
By Paula Elliot \\ Reference Librarian \\ Washington State University
}

\section{How to promote the library's literature collection through} a summer series of readings.

\begin{abstract}
$\mathbf{T}_{\text {t }}$ he fountain outside of Farrell Library is one of the attractive elements on the Kansas State University campus, as it catches the July sunlight and sprays in the breeze. On Thursday mornings in summer, a large and hopeful sign occupies the walkway near the fountain, and when the Kansas breeze is stiff the sign falls over. A thoughtful passerby will right it, perhaps responding to its message, as many will when it is in place. It reads, "Story Today at Noon," and serves as an invitation to pause in the middle of the work-day for some entertainment at the library.

"Short Story Classics" is a program which, for the past two summers, has offered small but satisfied audiences a noontime diversion in hearing short fiction read aloud. It had its beginnings in a fruitful collaboration with Antonia Pigno, the Minorities Resource Center librarian and now head of specialized collections at Farrell Library. I had recently entertained a friend by reading aloud the stories of a newly-published author, and encouraged by the enjoyment we both experienced, I suggested to Antonia that we might present a "story hour" at the library, reading the short works of established writers. I had mentioned it to the right person. In her position at the library, Antonia Pigno was long experienced at developing special programs, and was enthusiastic about implementing the plan. She approached the associate dean, Virginia Quiring, who championed the proposal to a somewhat resistant library administration, and received approval for the two of us to co-coordinate
\end{abstract}

the first season. I assumed the coordination of the second season, aided by Nancy Wootton, library assistant in the Audiovisual Department. The support of Virginia Quiring, and the energetic and creative contributions of Antonia and Nancy are gratefully acknowledged in making the program a reality.

At Kansas State University, "Short Story Classics" is a series of readings which, during July and August, has attracted weekly audiences numbering as many as forty. The program finds its ancestry, obviously, in the library-sponsored "story hour" of our childhood. This report focuses on the process of selecting stories and readers, promotion and publicity, and public response to the program, and offers guidelines for the development of such a program at other institutions. It asserts the principle that the library exists not only to support teaching curricula and research, but also to foster the intellectual and cultural life of the academic and civic community which it serves.

\section{Naming the program}

An entire generation remembers the scene at the public or school library: a herd of children squirming impatiently on makeshift sit-upons, while a librarian read aloud. (Another generation coming along is experiencing the same thing.) We also remember that hushed and attentive herd, each child quiet, rapt, maybe open-mouthed, sitting crosslegged or perhaps in that rubber-kneed, feetsplayed-out-behind position that only kids can get 
into...can you see it? "Story Hour": The title suggested something a little less than dignified for academe. And so at Farrell Library the event took on a classy name: "Short Story Classics." But in fact "Story Hour" is what it is, and in publicizing the event one is hard-pressed to circumvent the phrase. One publicity article (The Collegian, July 9, 1983) began: "Remember sitting with other children at the knee of a librarian as she read a fascinating story on a summer afternoon? Well, those days of the afternoon story hour are back..." Old traditions die hard. There's a case for calling it as you see it.

\section{Planning the program}

Once past the basic concept, "Short Story Classics" begins to deviate from the old library "Story Hour." Where story hour was typically presented by one reader - the librarian-all the time, we felt that an attractive variety could be achieved not only in the material selected, but in the readers themselves. This is where a team approach is preferable to single-handed planning. Brainstorming is essential. So are contacts. Between us, Antonia Pigno and I knew a number of likely readers, and together we planned whom we might approach with an invitation to read. In our prospective readers we looked for prior experience, such as poetry readings or amateur theatre, visibility and popularity on campus, a balance in genders and vocal qualities, and a fair and wide-spread representation of library and academic departments. Readers came from among such diverse academic areas as biochemistry, architecture, English, the dean's office; and within the library from areas such as audiovisual, circulation, the minorities center, and reference.

\section{Selecting the stories}

Variety was the primary criterion, but choosing material happened in a number of ways. Both coordinators knew of certain stories which they wanted to read or have read. In some instances the coordinators would match stories to readers, and in others, invited readers would select their own stories. The advice which one reader (a poet) gave to another (a writer of fiction), was "Just pick something you'd like to have written yourself." When the reader personally identifies with a story, it is obvious in the delivery. Someone with a Southern heritage read Eudora Welty, a feminist read Tillie Olsen, and an outstanding amateur actor, a scientist by discipline, gave a chilling rendering of "The Use of Force" by William Carlos Williams. A resource person with a strong literary background (such as Antonia Pigno possessed) can make story selection less time consuming and frustrating. When the choice is left up to the readers, it is essential to obtain a synopsis of the proposed story, so that it may be evaluated for its compatability with others on the program. (This synopsis is also useful in publicity.) Some prospective readers had definite ideas about what to read; others willingly accepted suggestions, or needed time to consider different options. (A complete list of stories, authors, and readers appears on the next page).

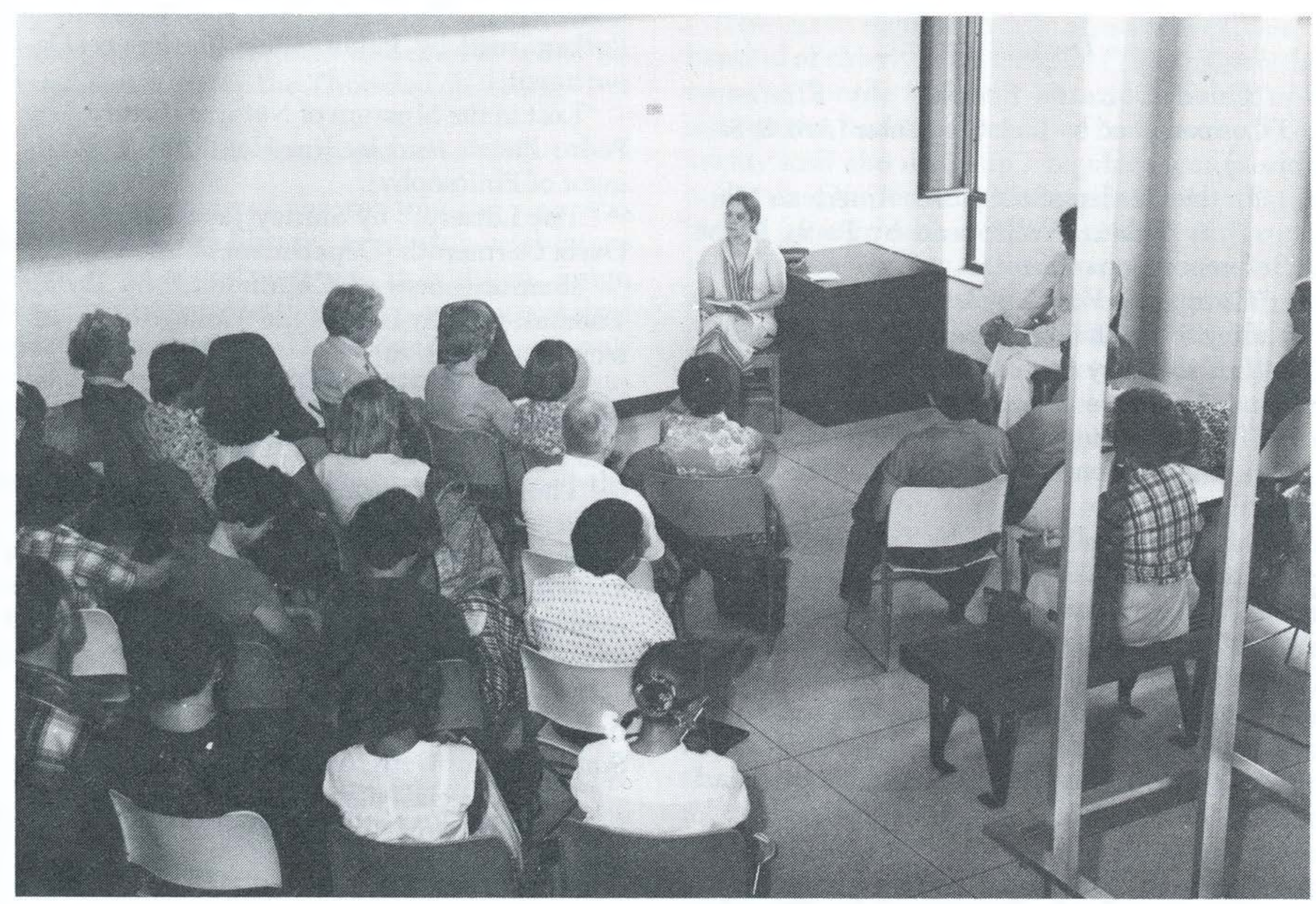

Calista Hull reads a short story at KSU. 


\section{When and where}

It was determined that the noon hour was the appropriate time to hold the readings. Traditionally at Kansas State University, numerous entertainment events and fitness activities are available over the noon hour, sponsored by the student union, the recreational services office, or the theatre department, for example. Fewer options occur in

\section{Readers came from diverse}

\section{academic areas.}

the summertime, so the library was able to fill a need. Because of prohibitive heat outdoors, the readings were held on a open landing, halfway up and halfway down the library's wide, window-lit staircase. The site has been less than optimal. Noise from the lobby travelling up the stairwell was something of a distraction. And though the stairwell was expansive and light, ultimately the air conditioning did not function there. On one impossibly sultry day, locked windows were opened on the landing, to make the environment more comfortable. Listeners settled early near them, wel- coming the breeze. During the hour, a violent wind developed, embellishing a forceful and dramatic reading, and a storm broke, inconveniently raining on some of the window seats. Visitors cooperatively moved aside so the windows could be shut, and the reading went on. The landing site had an advantage of being easy to locate, and it was accessible to passersby going up and down stairs. If seating was inadequate, the audience could (and did) overflow onto the stairs. On extremely hot occasions, the readings were moved off the landing into a corner of the third floor reading room. A more ideal location will be sought for future readings at the library.

\section{Publicity}

Introducing "Short Story Classics" was at the outset a multifaceted task. It was strongly felt by the coordinators that a personal approach was extremely desirable. In addition to contacting the Office of University Relations, which at Kansas State University acts as a campus-wide clearing house for news releases, the coordinators wrote personal letters to faculty and University officials who would find the library's offering of interest, and whose influence might encourage others to attend. A personal letter to the editor of the local newspaper resulted not only in advance publicity, but in a review of the first reading. Since both of the coordinators did a lot of personal contact work on campus, each had an opportunity to tell many people

\section{Short story classics read at the Farrell Library}

\section{The first season}

"Good Country People," by Flannery O'Connor; read by Jack Carpenter (Arts \& Sciences).

"In the Garden of the North American Martyrs," by Tobias Wolff; read by Paula Elliot (Reference Department).

"Gimpel the Fool," by Isaac Beshevis Singer; read by Steve Heller (Department of English).

"Lullaby," by Leslie Silko; read by Antonia Pigno (Minorities Resource Center).

"The Other Side of the Hedge," by E.M. Forster; read by Ben Nyberg (Department of English).

"I Stand Here Ironing," by Tillie Olsen; read by Calista Hull (Circulation Department).

"The Use of Force," by William Carlos Williams; read by David Cox (Department of Biochemistry).

"Forever and the Earth" and "Have I Got a Chocolate Bar for You," by Ray Bradbury; read by Pat Weisenburger (Architecture and Design Library).

\section{The second season}

Parker; read by Paula Elliot (Reference Department).

"Lost in the Museum of Natural History," by Pedro Pietri; read by Jim Hamilton (Department of Philosophy).

"The Lottery," by Shirley Jackson; read by Darla Germeroth (Department of Speech).

"Reminiscences of Childhood," by Dylan Thomas; read by Ifan Payne (College of Architecture and Design).

"The Cut-Glass Bowl," by F. Scott Fitzgerald; read by Nancy Wootton (Audiovisual Department).

"The Earthquake in Chile," by Heinrich von Kleist; read by Ron Hoffman (Media Center, College of Education).

“A Summer's Tragedy," by Arna Bontemps; read by Jeannette James Saxon (Department of Theatre).

"Eupompus Gave Splendour to Art by Numbers," by Aldous Huxley; read by Carolyn Smith (Serials Department).

“The Artificial Nigger," by Flannery O'Connor; read by Don Hedrick (Department of English).

"The Standard of Living," by Dorothy 
about the upcoming series. Word of mouth is a powerful publicity agent. With the mailings out, a three-phased flyer campaign was instituted. In the middle of May, a small handbill appeared around the library and around campus, simply announcing that "Short Story Classics," a series of readings, would occur at the library during June and July at twelve noon on the third floor landing, andsorry, no lunches, please. Shortly afterward, a letter-sized listing of stories and readers was mailed out to all participants and other interested persons. At the end of May a bright yellow poster appeared, not only listing stories and readers, but also containing a brief but enticing blurb for each. All flyers and posters were low-budget, quick-production endeavors, photocopied in-house at no particular expense. Posters were placed on campus bulletin boards, and distributed to academic departments by student assistants. The Collegian, the campus newspaper, responding to a personal letter and the University's news release, sent a student reporter each year to talk with the coordinators of the series. This was the librarian's moment to remind the campus population that the library happily provides recreational reading as well as course-related resources.

In planning the series Antonia Pigno had suggested that the readings be taped, in a recording session separate from the public events. Readers were scheduled to record with the Audiovisual Department, which oversaw the technical details. In 1982 these tapes were donated to the Manhattan Public Library for use in its talking books program. In 1983 the recordings were used in summer English classes. Flyers out, phone calls made, interviews given, and tapings underway, what remained was to enjoy the Thursday offerings.

\section{At the event}

On the morning of the reading the sign was placed outside the library, as much a celebratory gesture as an advertising one. In addition, a sign giving directions to the third floor landing was strategically placed inside. The design of both signs allowed for a space in which the week's story, author, and reader could be advertised. At the stroke of noon (prudently waiting for the carillon to finish playing), one of the coordinators announced the day's reader, making a brief introduction. The reader then introduced the story to be read, commenting on the author and the work. The extent of the commentary varied, according to the readers' concerns.

\section{Who attends?}

Students, faculty, office workers at the university, and townspeople were the groups that made up the audience. Some (perhaps half) were regulars, faithfully coming each Thursday at noon. Others were one-timers. Some came to hear a particular story, others to hear anything. Some came because they knew the reader, or the author, or the title; others came because they didn't. From week to week it was difficult to discern a pattern of attendees and their reasons; an informal survey corroborated the varied and absolutely unpredictable representation in the group. Attendance seemed higher in the first year than the second, but no conclusive head counts were made. On good days,

\section{Story selection did not affect attendance.}

roughly forty people were in the audience. On the worst, there were a lonely six.

\section{Audience response}

The survey, administered on the last day of the second season, was intended in part to discover story preferences. Results, however, suggested that the preferences of the audience were as varied as the individuals in the group; what one person liked, another one didn't. Story selection does not appear to affect attendance significantly. The survey revealed that many different media reached those who attended. Radio, newspapers, posters, and word of mouth all had contributed to publicity.

The most regular group of attendees were a handful of elderly townspeople. (This suggests that a market for the academic library's offerings exists outside the traditional campus community.) University staff also made up a regular segment of the audience. One research biologist indicated that she looked forward each week to the event. A secretary said she marked her calendar in advance for the summer. A journalist wrote to the dean of libraries, commending the series and adding: "I think such efforts go a long way towards reintroducing people to the pleasure libraries have to offer. Just as important, that pleasure is tinged with the bittersweet realities of life. It all serves to remind us of something we often forget-our common humanity." He returned in the second season and brought friends. According to the survey, the audience observed the same drawbacks to location as did the coordinators. Some remarked that it would be favorable if lunches could be eaten during the readings. More than one asked that the event be yearround. Several expressed genuine appreciation for the library's efforts, and all professed a willingness to support future similar programs. Preferences were indicated for stories with a simple narrative line and discernible, traditional structure. Requests were for foreign literature read by native speakers, especially third-world stories, and for a 
continued variety in selections. One respondent simply said, "Surprise me."

These remarks encouraged the library to continue "Short Story Classics." Respondents' suggestions will be taken into account in planning future seasons. The list of prospective readers is in process at this writing.

A series of readings is one way in which the enjoyment of literature may be promoted. It serves to remind all comers that reading for pleasure is one of life's satisfying diversions, and that being read to is just plain entertaining. As one attendee wrote, "Thanks for bringing back oral interp as an art form." As much as a series of readings entertains the listener, it also affords the invited readers an opportunity to be seen in a different and perhaps unexpected light, and to contribute their time and talent to the community.

\section{Getting started}

Those wishing to create a series of library-based readings might consider the following suggestions:

-It is advantageous for more than one person to be involved in the coordination of the program. A team assures a diversity of literary and artistic backgrounds, concerns for the library, and contacts in the community. The collaboration also provides for back-up during summertime vacation schedules.

- A variety of stories and readers must be achieved. A literary background is helpful in making decisions. Additionally, suggestions can be garnered from friends and colleagues. Short Story In$d e x$ and the ever-available subject catalog will yield anthologies of classics and recent prize winners. Little magazines can be explored for new fiction.

-In publicizing the series, a personal letter campaign is helpful. Posters and flyers should be simple, direct and attractive, and might include blurbs about each story.
- Select a quiet, but easily accessible location. Provide comfortable seating, perhaps setting up a stool or a raised area for the reader. In determining the time for the readings, consider your library's and your institution's daily routine and traffic flow. Depending on your library's policy, establish guidelines for eating and drinking during the readings.

- Your readers are contributing valuable time and ability, and deserve recognition. Remember to thank them verbally and in writing for their participation in the library's efforts. As at KSU, a letter might come from the dean or director of the library. If, as at KSU, a library staff function occurs during the summer, make your readers the honored guests.

- Take pleasure in the project. It requires extra work, efforts at communication, perhaps a creative overload. But the undertaking yields satisfaction on many levels.

We are reminded that the library in our culture has traditionally fostered the pursuit of human values, and has been a refuge from daily concerns. In our time, the library threatens to relinquish its responsibility for the humanistic enterprise. Our concern with the efficient organization and transfer of "information" has resulted ironically in our failure to recognize the varieties of information, which include among them the literary and artistic experience. Outreach offerings reestablish the library as a place of pleasure as well as of work. If the academic community exists to transcend the world at large rather than reflect it, then the academic library, in its increased visibility, can ideally contribute to the academic mission, not only by protecting and providing its holdings, but by promoting them with enthusiasm and with pride.

Editor's Note: The author is currently coordinating a similar series of short story readings at Washington State University.

\section{CLR selects four ACRL members as 1984-85 management interns}

The Council on Library Resources has selected six librarians for its 1984-85 Academic Library Management Intern Program. Four of them are ACRL members: Joseph J. Branin, University of Georgia; Nicholas C. Burckel, University of Wisconsin-Parkside; Carolyn Louise Harris, Columbia University; and Paul Douglas Metz, Virginia Polytechnic Institute and State University. The others chosen are James Alan Cogswell, Princeton, and Arlyne A. Jackson, MIT.

The objective of the Management Intern Program is to help outstanding individuals broaden their experience and enhance their management skills. Interns spend one academic year away from their home institutions, working with library directors and senior administrators at research libraries. Each participant receives a grant (up to a total of $\$ 25,000$ ) equal to the salary and benefits that would have been paid by the home institution.

Libraries at the University of Chicago, Columbia University, Emory University, University of Georgia, Johns Hopkins University, and Northwestern University will serve as hosts for the 1984-85 interns. 


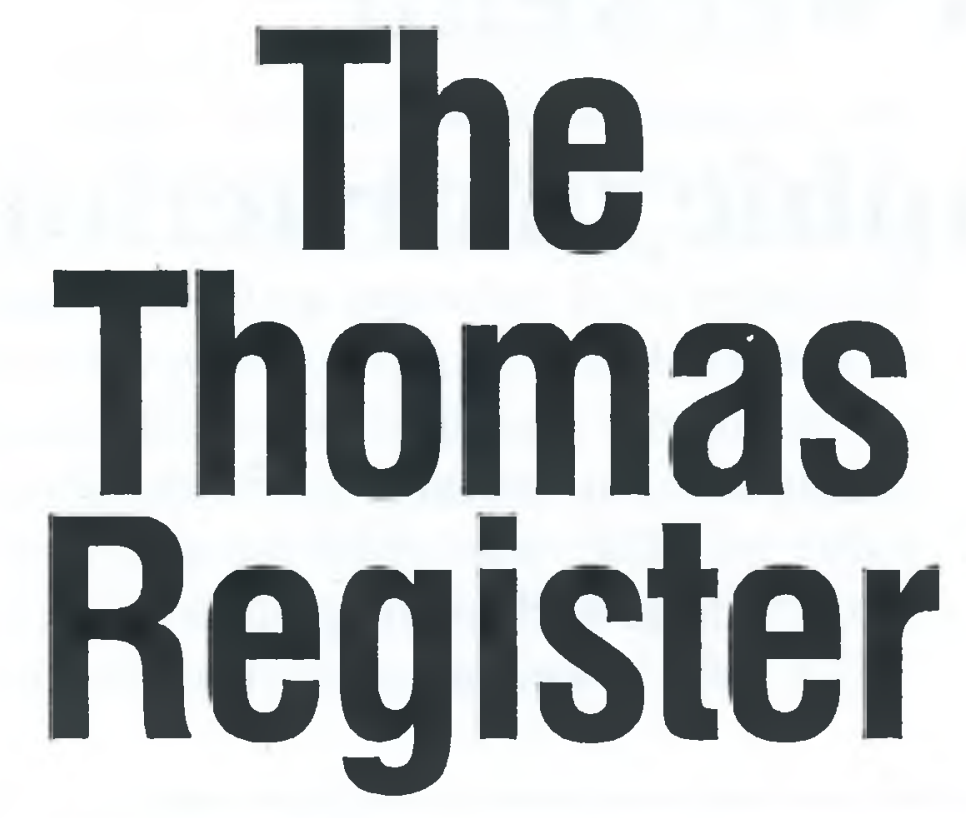

On Microfilm. . from Research Publications

\section{Easy Access to a Renowned Reference}

Vital information on American business and industry is easily accessible with The Thomas Register. Available on a subscription basis with backfiles from 1905 to 1983 , this publication includes three major categories:

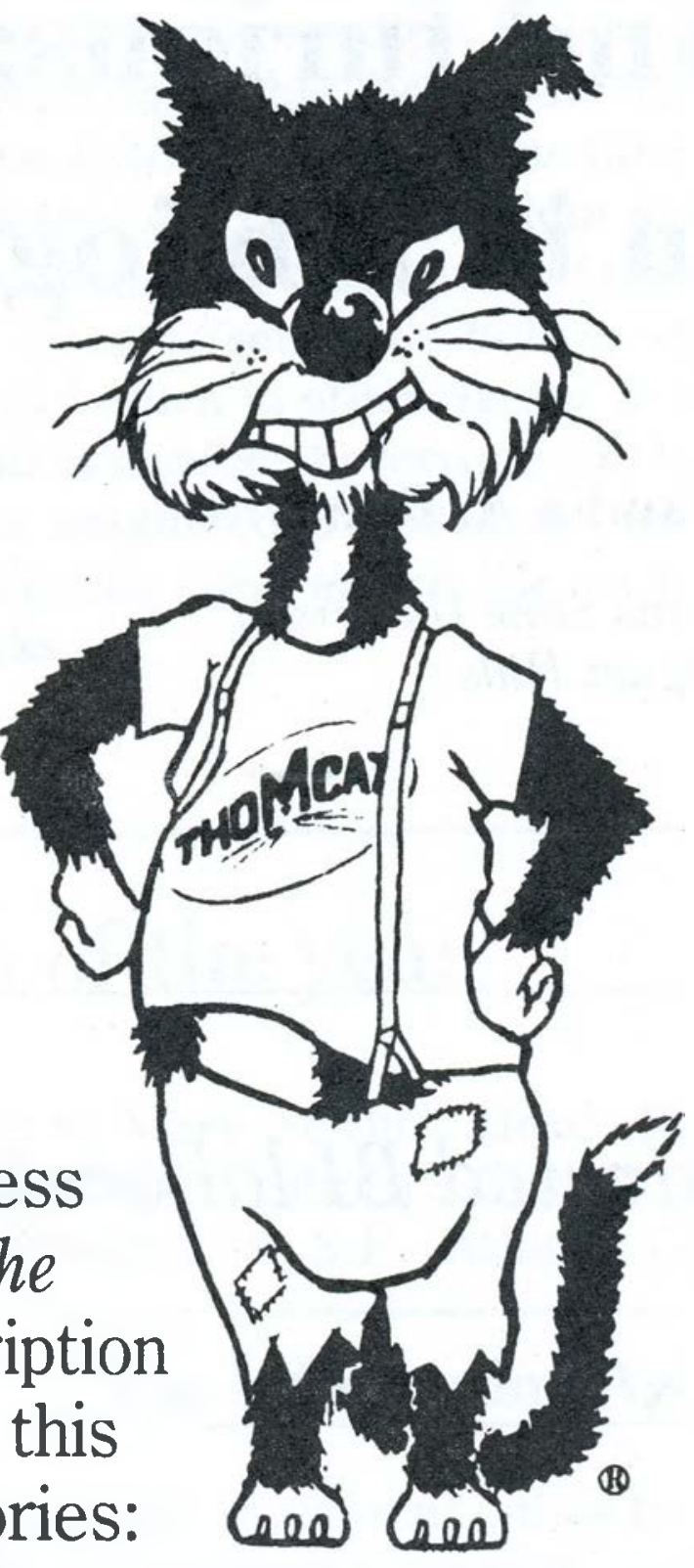

- Products/Services - lists thousands of specific products and services

- Company listings - provides detailed information on specific companies

- Thomas Register Catalog File (THOMCAT) provides buying and specifying information from nearly 1,000 companies and is cross-referenced with the Products/Services file.

Covering the years 1905 to the present, this comprehensive reference tool is a valuable historic, social, and technical aid for researchers of American business, industry, and commerce.

Thomas Register

Reels $\underset{\text { Reels }}{\stackrel{\text { Standard }}{\text { Starvue }^{\circledR}} \text { Reels }}$ Cartridges

$\begin{array}{lrrrr}\text { 1905-1983 Backfile } & 250 & \$ 9,500 & \$ 9,800 & \$ 10,500 \\ \text { 1984 Subscription } & & 575 & 595 & 650\end{array}$

To order, or for more information, call or write:

Research Publications

12 Lunar Drive/Drawer AB

Woodbridge, CT 06525

(203) 397-2600

TWX: 710-465-6345

FAX: 203-397-3893
Outside North and South America: P.O. Box 45

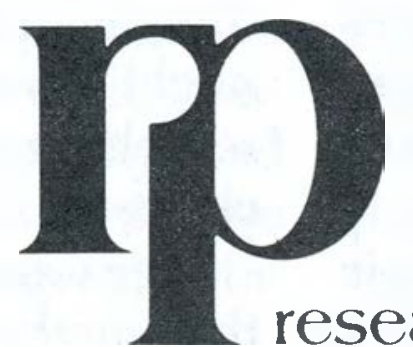

Reading, RG1 8HF England

TEL: 0734-583247

TELEX: 848336 NADL G 